\title{
THE CHRONOLOGY OF COASTAL MORPHOGENESIS AND HUMAN SETTLEMENT ON AITUTAKI, SOUTHERN COOK ISLANDS, POLYNESIA
}

\author{
MELINDA S. ALLEN \\ Department of Anthropology, Bishop Museum, Honolulu, Hawai'i 96817 USA
}

\begin{abstract}
Twenty-seven ${ }^{14} \mathrm{C}$ determinations from Aitutaki, southern Cook Islands inform on human settlement and Holocene coastal processes. I examine sedimentary, radiometric and archaeological data from Aitutaki with reference to regional evidence for a minor Holocene sea-level regression, which are in general agreement. Related processes of shoreline progradation and aggradation created near-shore environments conducive to human habitation, directly evidenced by $c a$. AD 900-1200. Nevertheless, biotic materials associated with this early cultural stratum suggest human colonization prior to this time. Archaeological preservation and recovery also may have been affected by changing sea level and related sedimentary processes.
\end{abstract}

\section{INTRODUCTION}

Geological and archaeological studies of Pacific coastal environments increasingly point to significant changes within the Holocene period. Among the more important contributing factors has been a minor Holocene sea-level regression, now demonstrated for several South Pacific localities. While the data are broadly corroborative with a decline of $1-2-\mathrm{m}$ magnitude, the timing remains controversial, and may not have been uniform throughout the region. Mangaia to the south and the Tuamotus to the east, both areas on the same tectonic plate, can be used as sea-level models for Aitutaki. On Mangaia, Yonekura et al. (1986) identified emerged wave-cut notches, benches and micro-atolls consistent with a sea-level stand $1.7 \mathrm{~m}$ above present levels, with a decline between $c a$. 3400 and $2900 \mathrm{BP}$. In the Tuamotus, cementation patterns in coral conglomerates document a gradual sea-level decline of $0.8 \mathrm{~m}$ between ca. 1500 and $1200 \mathrm{BP}$ (Pirazzoli et al. 1988). Not only does the time of the decline differ from that of Mangaia, but it is also a gradual rather than rapid fall. Given that the mechanisms behind this regression are not well understood, it is unclear how much variability we should expect in the timing, rate and magnitude of sea-level decline both within and across Pacific archipelagos.

Lower-order climatic trends may also have affected Pacific coastal regions. Although the evidence is limited, deriving mostly from high-altitude areas of New Zealand and New Guinea, temporal variation in temperature, precipitation and storminess are suggested, and would have affected sedimentation patterns, both at inland and coastal localities (Nunn 1991). Sedimentary regimes were altered further by agrarian human colonists, who began to settle Polynesia $3500 \mathrm{yr}$ ago. The relative impact of people versus climatic forces on Pacific landscapes, especially lowland areas, is a topic of much debate (e.g., Athens and Ward 1993; Kirch 1983; Nunn 1991; Spriggs 1981).

A suite of $27{ }^{14} \mathrm{C}$ determinations from seven localities on the almost-atoll (after Stoddart 1975) of Aitutaki contributes to these discussions of Holocene coastal processes in the Pacific and specifically in southern Polynesia. This paper reviews local sea-level decline, the age and development of Aitutaki's central western coastal features, the relative impact of people versus natural forces in shaping the coastal plain. I also discuss the timing of human colonization of the island and the character of settlement on Aitutaki's central western coastal plain.

\section{METHODS}

The dominant physiographic feature of Aitutaki is a roughly triangular lagoon surrounded by a $45-\mathrm{km}$ reef (Fig. 1). The Aitutaki mainland is the weathered remnant of the old volcanic core, mea- 
suring $c a .9 \mathrm{~km}$ long by $3 \mathrm{~km}$ wide. Thirteen coral detrital islets run along the eastern edge of the lagoon, a sand cay lies in the southwest corner, and two volcanic islets lie within the lagoon near its southern boundary.
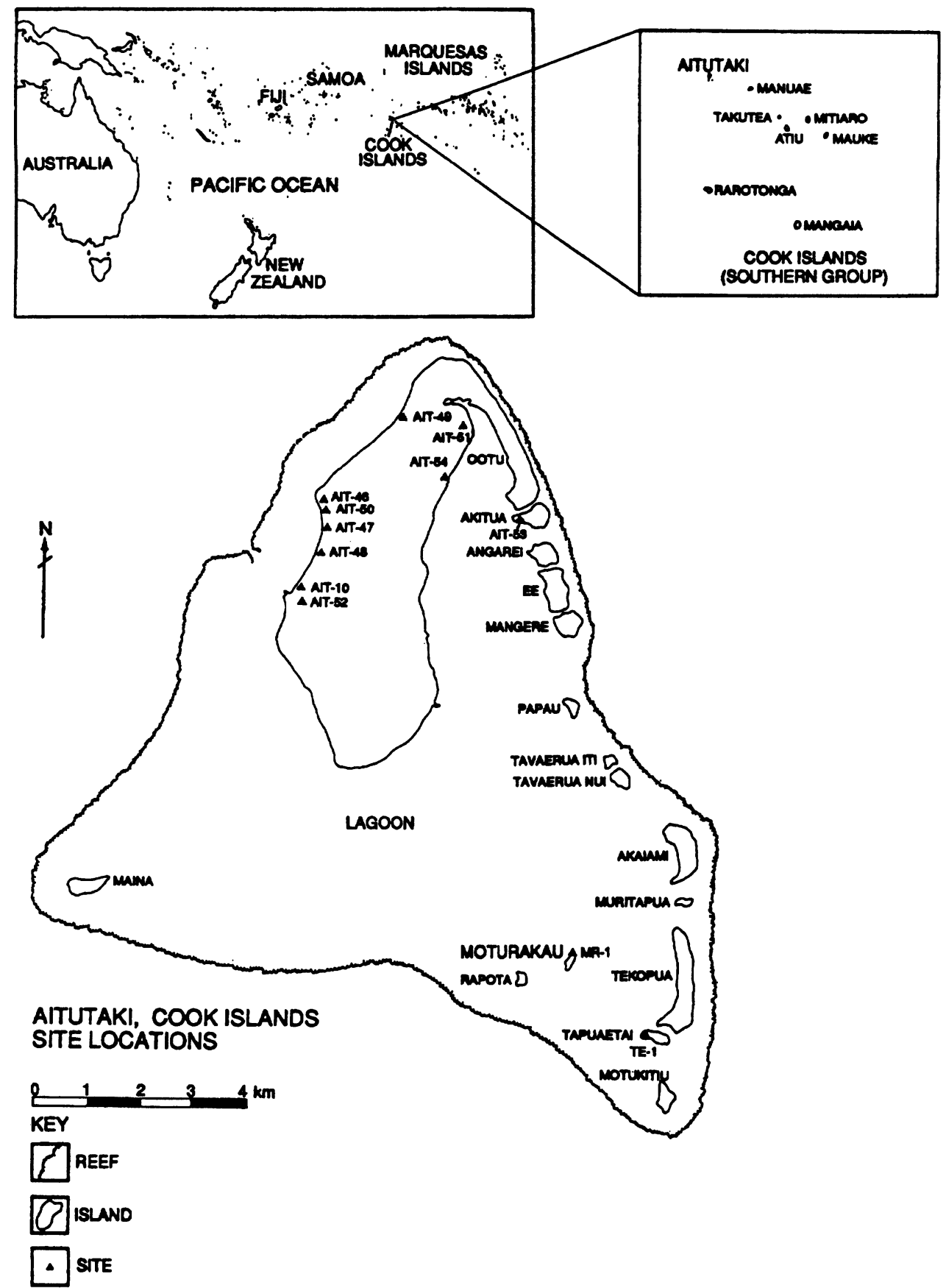

Fig. 1. Aitutaki, southern Cook Islands, showing locations of excavated archaeological sites 
The Aitutaki archaeological project focused on the central western coast of the main island (Allen 1992a; Allen and Steadman 1990) and the volcanic offshore islet of Moturakau, where a significant record of human occupation was identified previously (Allen and Schubel 1990). One objective was to locate early human settlements and evaluate the general framework of east Polynesian colonization. The subsurface survey was guided by a geomorphic model constructed from regional patterns and limited local evidence. We placed auger transects perpendicular to the coast, from the shore inland to the volcanic slopes. Then we opened shovel trenches at strategic locations to record and sample sedimentary attributes and cultural components of the subsurface strata. Based on the survey results, we selected several localities for controlled stratigraphic excavations of cultural deposits. I report here ${ }^{14} \mathrm{C}$ determinations from 6 loci of cultural deposition and 1 non-cultural context. At each locality, multiple cultural strata, alternating with storm deposits, were found. I term these cultural strata occupations, as each represents a discrete period of time in terms of cultural deposition, and in some cases, the range of ${ }^{14} \mathrm{C}$ dates.

The model assumed relative tectonic stability and shoreline progradation coincident with sea-level decline after 1200 BP (Allen 1992a). Early occupations were predicted to be located inland and possibly deeply buried. However, augering and trenching to $3.5 \mathrm{~m}$ or more in several locations failed to identify deep cultural deposits near the base of the volcanic slopes. To the contrary, most cultural deposition in this area was near-surface and associated with historical artifacts. In areas near the present shoreline, cultural occupations (indicated by charcoal-enriched sediments with artifacts, faunal remains and in-situ architectural features) alternate with largely inorganic, coarseto-medium-grain sands with occasional clastics deposited by high-energy storms (see Allen 1992a, for details). In some cases, dispersed charcoal and/or isolated features, such as hearths, indicated more ephemeral cultural activity.

Excavations in two small rockshelters on the offshore islet of Moturakau, in contrast to the mainland localities, revealed that cultural deposition in this setting was nearly continuous, with little interruption by storm activity. Faunal remains and the portable artifact assemblages indicate that the islet was heavily used as a base camp for fishing forays and for the early stages of basalt adz manufacture. Despite the density of cultural materials found on Moturakau, functional analysis of the artifacts and features (e.g., hearths, subterranean ovens and postmolds) evidence short-term, periodic use of the islet, rather than extended, permanent occupation (Allen 1992a).

\section{RESULTS AND DISCUSSION}

\section{Radiocarbon Analyses}

The strategy of the present project was to date the basal occupation at each locality to determine the onset of human occupation, and less directly, late Holocene stabilization of the coastal plain. In areas of cultural deposition, we sampled in-situ burn features (e.g., hearths) whenever possible. Otherwise, we collected samples from discrete sedimentary layers using 7 -mm screens. Most ${ }^{14} \mathrm{C}$ samples were wood charcoal; two were shell. Figure 2 summarizes the results of $15{ }^{14} \mathrm{C}$ measurements from 5 mainland localities. Also included are three samples processed by the New Zealand Radiocarbon Laboratory at Lower Hutt that Bellwood (1978) previously reported $\left(\delta^{13} \mathrm{C}\right.$ values were estimated for these samples, after Stuiver and Polach 1977). Another $12{ }^{14} \mathrm{C}$ samples were taken from the 2 Moturakau shelters (MR-1) (Fig. 3).

All samples from the present project were analyzed by Beta Analytic, Inc. of Coral Gables, Florida. Wood-charcoal samples were pretreated for carbonates and humic acids (Tamers, personal communication 1989-1991). Benzene synthesis and counting were reported as normal in all cases. ${ }^{13} \mathrm{C} /{ }^{12} \mathrm{C}$ 


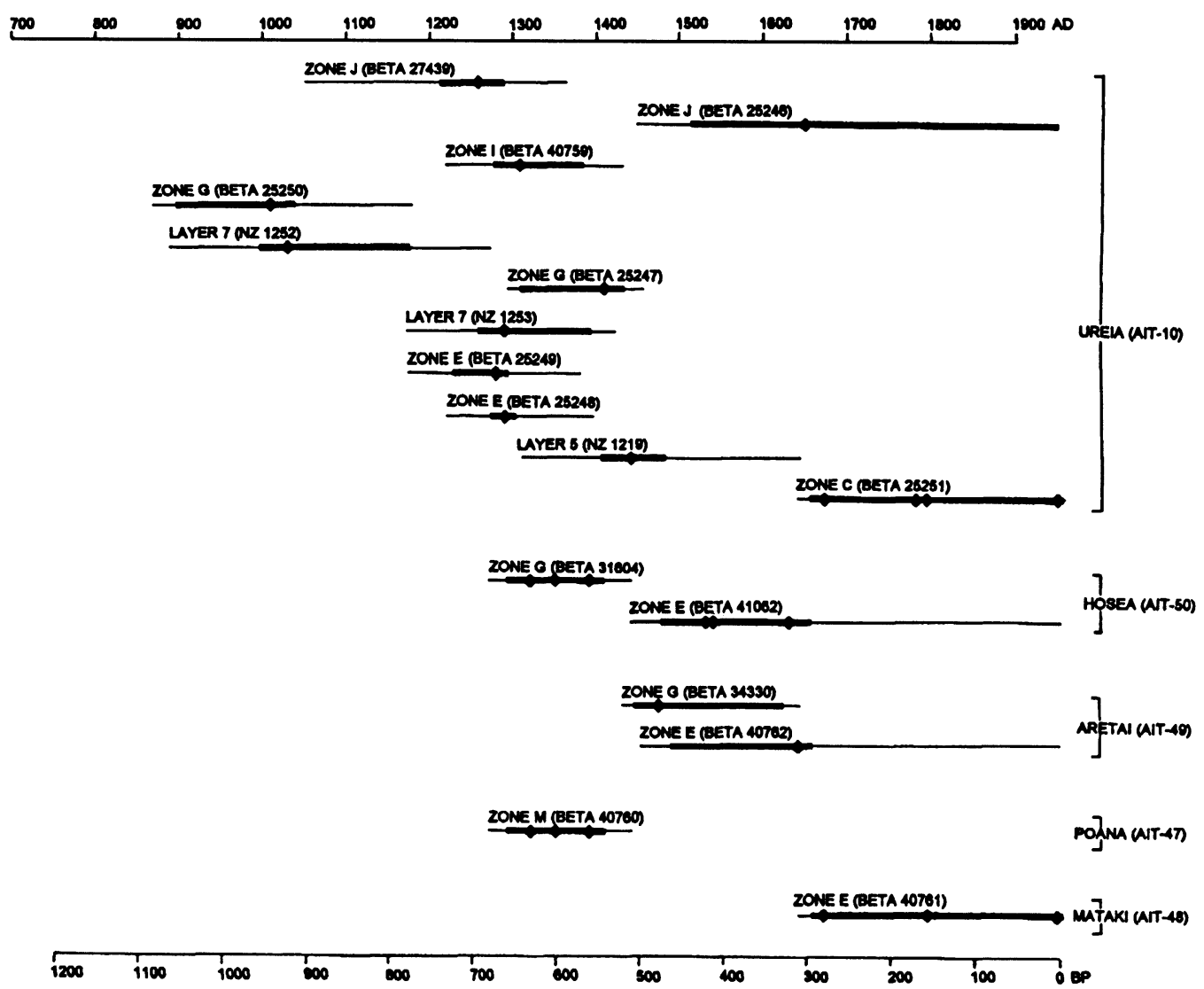

Fig. 2. Calibrated age ranges $(-=1 \sigma ;-=2 \sigma)$ and intercepts $(\diamond)$ for ${ }^{14} \mathrm{C}$ dates from mainland cultural layers

ratios were measured routinely and form the basis for the ${ }^{13} \mathrm{C}$-adjusted "conventional ${ }^{14} \mathrm{C}$ ages" reported here (after Stuiver and Polach 1977). These conventional ages were calibrated using the Stuiver and Reimer $(1986,1993)$ CALIB program (Version 3.0.2) for terrestrial samples, which is based on Stuiver and Becker $(1986,1993)$.

Three species comprised Beta-41061 (Asaphis violaceus, Fragum fragum and Rhinoclavis aspera), whereas Beta-40759 consisted of a culturally modified Pinctada margaritifera valve. The two shell samples were pretreated by etching away the outer shell layers with dilute acid (Tamers, personal communication 1990) before collecting $\mathrm{CO}_{2}$ for benzene synthesis. As with the wood charcoal samples, ${ }^{13} \mathrm{C} /{ }^{12} \mathrm{C}$ ratios were established; conventional ages were calibrated for the shell samples with the marine component of the Stuiver and Reimer $(1986,1993)$ CALIB program, as based on Stuiver, Pearson and Braziunas (1986). The Society Islands $\Delta R$ value of $45 \pm 30$ (from Stuiver, Pearson and Braziunas 1986) was used in calibrations, given that no $\Delta R$ value has been established for the southern Cook Islands.

Prior work by Bellwood (1978) at the Ureia site (AIT-10) had identified an in-situ cultural occupation dated to cal AD 1000-1180 (NZ-1252) (Zone G of the present study). In 1987, we uncovered additional cultural materials $c a .50 \mathrm{~cm}$ below this occupation (Zones I and J). Both of these zones were storm deposits, characterized by finely graded beds and coral clastics, which incorporated 


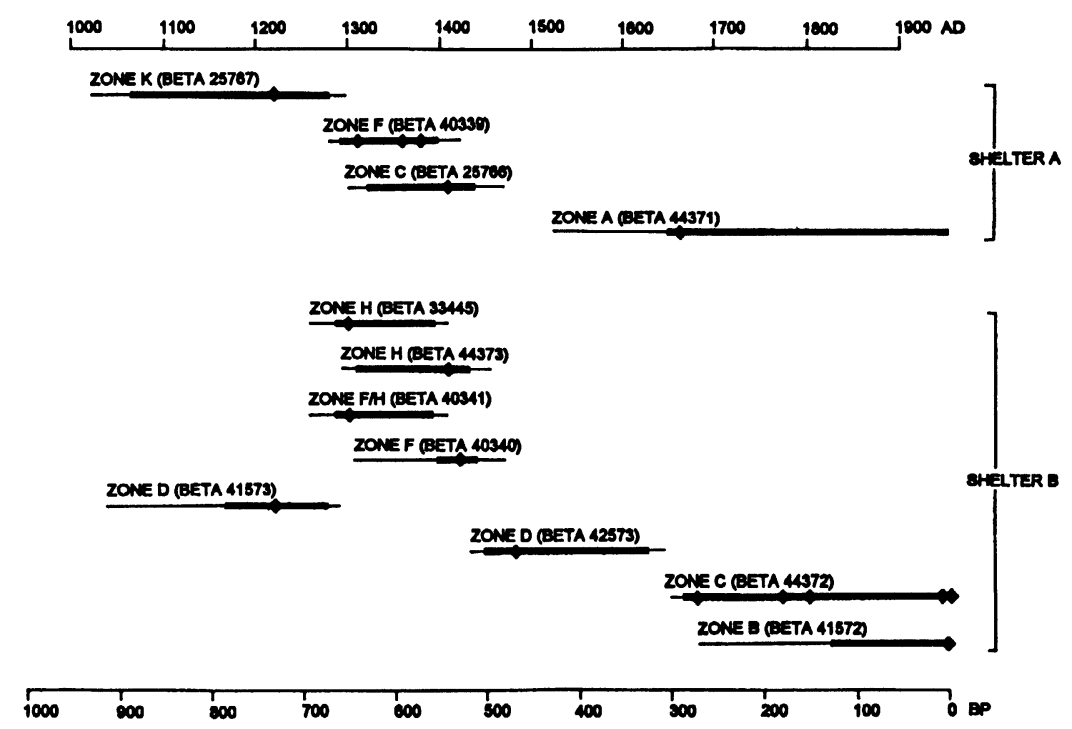

Fig. 3. Calibrated age ranges and intercepts (key as in Fig. 2) for ${ }^{14} \mathrm{C}$ dates from Moturakau cultural layers

reworked cultural materials. Although their stratigraphic positions suggest that these cultural materials are older, the associated ${ }^{14} \mathrm{C}$ determinations are problematic (see Fig. 2). All three calibrated dates from Zones I and $\mathrm{J}$ are unexpectedly young, although two overlap with samples from Zone $\mathrm{G}$ at two standard deviations. Sample Beta-25246, a small concentration of charcoal, could be materials vertically displaced from Zone $\mathrm{C}$ by land crabs. However, the large pearlshell piece comprising Beta- 40759 would have been more difficult to move. Moreover, cultural use of pearlshell on Aitutaki is largely restricted to the early period (Allen 1992b).

Zones $\mathrm{E}$ and $\mathrm{C}$ at Ureia (AIT-10) are also in-situ cultural occupations, and together with the intervening storm deposits, mark a period of shoreline aggradation. ${ }^{14} \mathrm{C}$ determinations from Hosea (AIT-50) and Aretai (AIT-49) represent the earliest (Zone G) and subsequent (Zone E) occupations at these two localities. The Poana sample (AIT-47) was taken from a small charcoal concentration at $125 \mathrm{~cm}$ below surface. Although the sample comes from the most basal in-situ cultural feature excavated, two thin (2-3 cm) organic-enriched layers, representing soil development or human activity, were identified at $147 \mathrm{~cm}$ and $196 \mathrm{~cm}$ below surface. At Mataki (AIT-48), the basal in-situ occupation was dated; $c a$. $70 \mathrm{~cm}$ below this occupation is an undated, $3-5 \mathrm{~cm}$ thick, loamy gray sand with charcoal flecks.

Figure 3 summarizes the ${ }^{14} \mathrm{C}$ determinations from the Moturakau shelters (MR-1). Zone $\mathrm{K}$, with an age of cal AD 1060-1280, is the basal cultural strata in Shelter A. Little charcoal was available from Zone K of Shelter B. However, Beta-41573 of Zone D suggests that activity in Shelter B was contemporary with that of Shelter A, although the sample's stratigraphic position indicates disturbance. Similarly, Beta-25766 may not date accurately the cultural activities associated with deposition of Zone $\mathrm{C}$. The reworking of older charcoal into stratigraphically superior positions is not surprising for a rockshelter deposit, and could reflect land-crab activity, storm surf or human disturbance.

\section{Coastal Morphogenesis}

A model of coastal morphogenesis emerges from the Aitutaki ${ }^{14} \mathrm{C}$ data, coastal topography and sedimentary evidence. The auger tests indicate that much of this central western plain is composed of 
marine sediments, with terrigenous sedimentation occurring only near the base of the volcanic slopes. Profiles along the auger transects (e.g., Fig. 4) reveal a well-developed beach ridge with a swale on the inland side. The swale is interpreted as the pre-regression shoreline, and, in at least two locations, was once a brackish water marsh. ${ }^{14} \mathrm{C}$ dates from the cultural occupations found within the beach ridge document the latest possible sea-level decline and initial growth of this feature. The oldest cultural stratum dates to $c a$. AD 1000, whereas basal occupations at five other localities are more recent (Fig. 2).

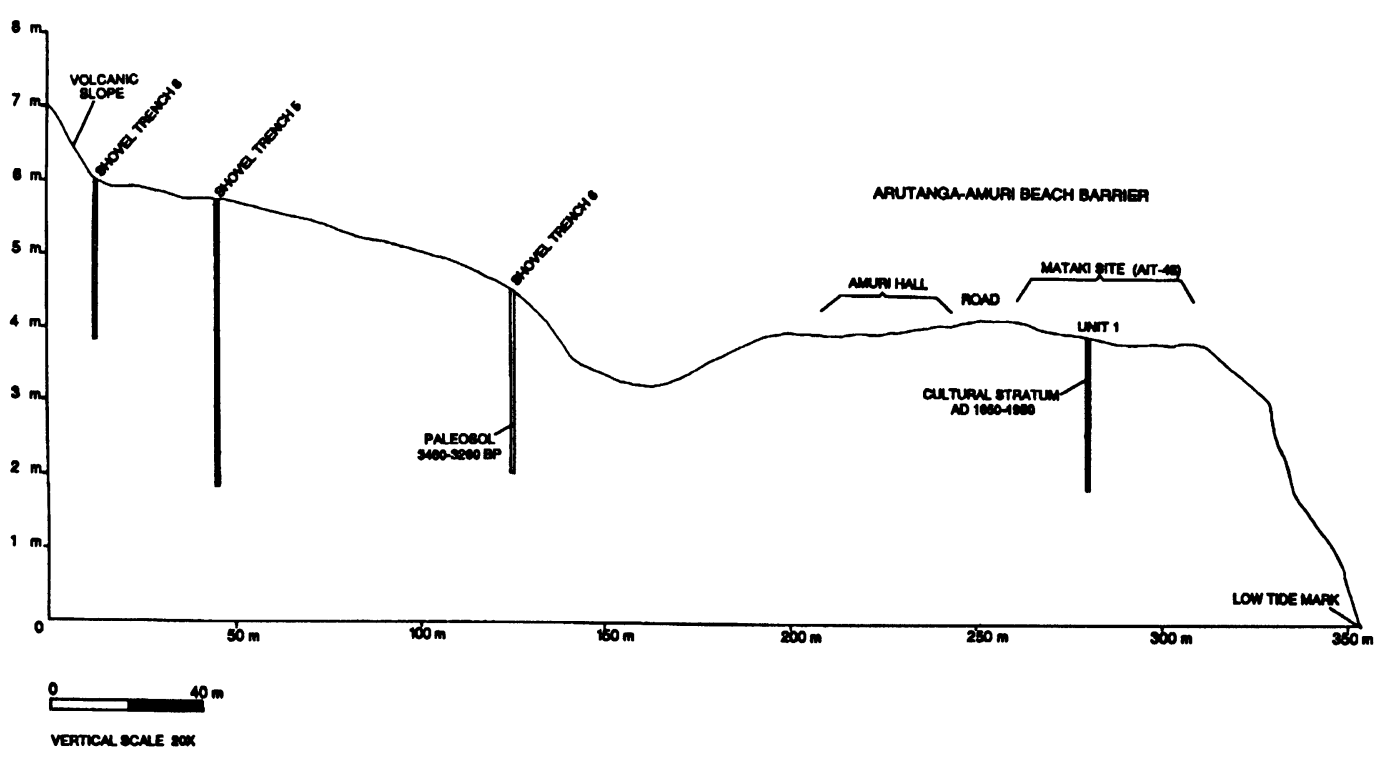

Fig. 4. Typical topographic profile across coastal plain, from base of volcanic slope to reef flat

Evidence from Aitutaki's offshore islets, while not directly informative about the timing of sealevel decline, is consistent with a pre-1000 BP date for this event. Stoddart (1975) reported dates of $2040 \pm 90(\mathrm{GaK}-3496)$ and $160 \pm 80 \mathrm{BP}(\mathrm{GaK}-3500)^{1}$ from conglomerate platforms of Akaiami and Muritapua Islets, respectively, indicating that they are geologically recent formations. Archaeological survey of 11 islets identified little evidence of prehistoric cultural activity and, with the exception of the Moturakau rockshelters, no temporal markers indicative of significant antiquity (e.g., pearl shell fishhooks, stylistically early adz forms, pottery) were found.

The vertical sedimentary profile from Ureia (AIT-10) suggests three environments of deposition through time, consistent with a prograding shoreline: 1) a relatively low-energy reef flat; 2) an active foreshore; and most recently, 3) a backshore beach ridge (Fig. 5). The active foreshore environment was first registered in Zones I and $\mathrm{J}$ and most likely was initiated by the minor Holocene sea-level decline, which also appears to have initiated aggradation. The beach ridge at Ureia formed episodically, building primarily through storm deposition, and, by cal AD 900-1200, had stabilized sufficiently to allow human colonization. A plot of the Ureia cultural occupations by age and depth below surface suggests that ridge growth was more rapid initially than during the last few centuries (Allen 1992a). Archaeological survey further reveals that over the last ca. $1000 \mathrm{yr}$, cultural activity

${ }^{1}$ These dates were not corrected for isotopic fractionation (e.g., ${ }^{13} \mathrm{C} /{ }^{12} \mathrm{C}$ ratios) (K. Kigoshi, personal communication 1994). 
on Aitutaki's central western coast was concentrated on the near-shore beach ridge. Settlement near the inland volcanic slopes occurred primarily, if not solely, in the historical (e.g., post-1773) period.

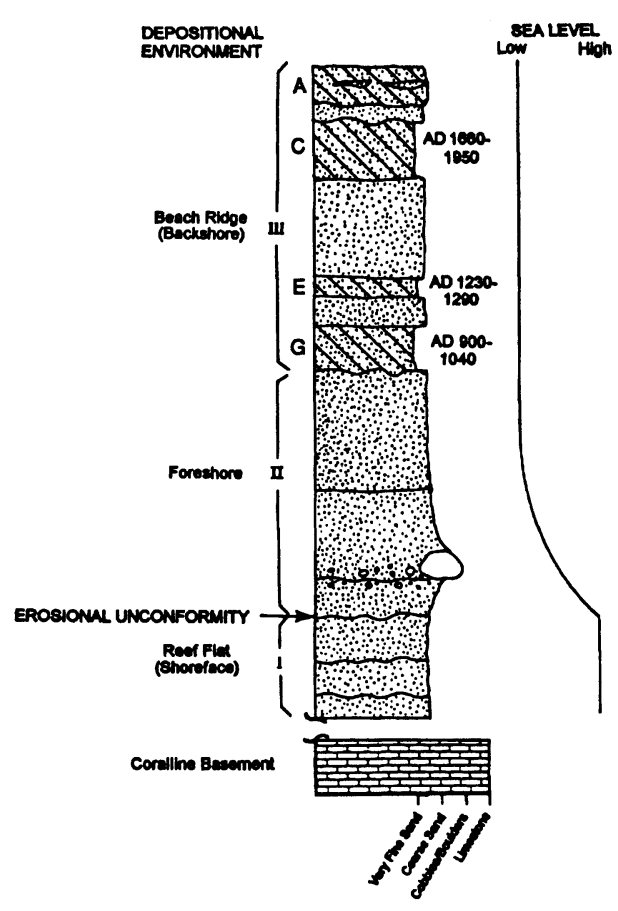

Fig. 5. Sedimentary profile from Ait-10, summarizing temporal changes in depositional environment
Concurrent with shoreline progradation, small near-shore wetlands developed in the backshore trough of the beach ridge (Fig. 4). These wetlands were a critical habitat for wet taro (Colocasia esculenta) cultivation, a highly valued traditional carbohydrate. One such coastal marsh remains at Ureia, whereas a historically known example was inland of the Hosea site (AIT-50). These coastal marshes were an important resource to Aitutaki's prehistoric inhabitants, being one of the few places on the island where wet taro can be grown.

Although much of the western coastal plain may have formed over the last $1500 \mathrm{yr}$ or so, a buried paleosol identified in one inland trench at $180 \mathrm{~cm}$ below surface dates to 3459-3258 cal BP (Fig. 4). A sample from below this paleosol, Beta-41061, was composed of fresh shells whose deaths probably preceded development of the A-horizon by no more than a few centuries. This comparatively early date suggests that at least some portion of the coastal plain was available for human habitation by ca. $3300 \mathrm{cal} \mathrm{BP}$. However, the area of exposed land was probably small and discontinuous along the coast. Further, if reef growth lagged behind sealevel rise prior to sea-level decline, as was the case in some settings (Nunn 1991), near-shore areas may have been particularly vulnerable to storms, potentially affecting archaeological preservation and recovery.

\section{Human Settlement}

The redeposited cultural materials found in Zones I and J at Ureia (AIT-10) are among the earliest evidence of human settlement in the southern Cook Islands (see also Kirch, Flenley and Steadman 1991). Although the ${ }^{14} \mathrm{C}$ determinations are ambiguous, the stratigraphic position of these materials ca. $50 \mathrm{~cm}$ below the cal AD 900-1200 in-situ occupation of Zone G indicates that they are at least slightly older. Zone G, dated by both Bellwood (1978) and the present project, is the earliest in-situ occupation presently known for Aitutaki. Recent augering, trenching and stratigraphic excavation elsewhere on the western coast (Allen 1992a) suggest that early activity was restricted to Ureia.

Nevertheless, the Aitutaki biota are strong evidence that the ca. cal AD 900-1200 occupation does not represent initial human colonization of the island. In particular, the avifauna is taxonomically poor, with only four native land birds recovered from the excavations at large (Allen and Steadman 1990; Steadman 1991). Relative to the avifauna in other early Polynesian sites and the modern fauna on other Cook Islands, that of Aitutaki both now and at ca. cal AD 900-1200 is limited. Likewise, the Ureia land-snail assemblage is dominated by anthropophilic taxa commonly associated with human habitation and gardens (Allen 1992a). Wood charcoal identifications are in basic agreement, and suggest that native forests had been reduced. In contrast, elsewhere in the Pacific, native 
species are typically well represented in colonizing human occupations. The palynology of Mangaia Island further supports the idea of pre-1000 BP human settlement in the archipelago. Kirch, Flenley and Steadman (1991) and Lamont (1990) record forest clearance with no subsequent regeneration as early as $c a .1600$ cal BP; recent analyses suggest human intervention as early as $500 \mathrm{BC}$ (P. V. Kirch and J. Ellison, personal communication 1993).

After $c a$. cal AD 900-1200, human settlement on Aitutaki's central western coast was generally continuous. The excavated occupations, dated both radiometrically and relatively, suggest continued population growth on this coast until the historical period (Fig. 2). Following European contact, there appear to be fewer settlements on this coast. Given the widespread and disastrous effects of European diseases elsewhere (e.g., Crocombe 1964; Ramenofsky 1987), a population decline in the historical period would not be unexpected. Other factors must also be considered in assessing postcontact patterns of near-shore settlement. For example, we identified several historical occupations near the volcanic slopes that may represent a post-contact shift in settlement.

The Aitutaki mainland excavations also point to periodic disruption of human settlement by highenergy storms. Early historical accounts describe the destruction of homes and crops by hurricanes, as well as the famines that often followed (e.g., Sunderland and Buzacott 1985). ${ }^{14} \mathrm{C}$ dates from Ureia (AIT-10) and Hosea (AIT-50) indicate that site abandonment of a century or more sometimes followed these storm events. However, at Aretai (AIT-49), the effects of storms are less apparent in the main occupation area, which showed relatively continuous settlement.

The ${ }^{14} \mathrm{C}$ evidence, in conjunction with coring, trenching and controlled excavations at several localities, hints at a second dimension of local settlement. From ca. cal AD 900-1400, human occupation is represented only at Ureia (AIT-10). Subsequently, settlements apparently shifted northward, including Hosea (AIT-50) and Aretai (AIT-49), with some activity at Poana (AIT-47). Shortly before western contact, populations again shifted south, with re-occupation of Ureia and the initial settlement at Mataki (AIT-48). These seemingly small-scale shifts could be an artifact of archaeological sampling, however. They may also indicate population mobility linked to shifting agricultural practices, akin to those described by Johnson (1967) for the 20th century.

\section{CONCLUSIONS}

Combined radiometric, archaeologic and sedimentologic evidence reveals the dynamic nature of Aitutaki's coastal region during the period of human settlement. The chronology of recent shoreline progradation and beach-ridge development on Aitutaki suggests these processes were initiated by Holocene sea-level regression at $c a$. 3400-1200 BP, a phenomenon well documented elsewhere in the region. The Aitutaki research also points to the relatively minor effect of human activities on coastal morphogenesis in this locality. Contrasting with studies elsewhere in the region, no significant terrigenous sedimentation occurs until late prehistory, and even then, the coastal plain is largely unaffected.

The ${ }^{14} \mathrm{C}$ findings of the present project support and augment those of Bellwood's (1978) earlier study. Although we identified cultural materials at deeper levels, the ${ }^{14} \mathrm{C}$ results are only slightly older than the cal AD 900-1200 in-situ occupation. The biota associated with the in-situ occupation, with relatively few native species and several anthropophilic taxa, suggests human colonization of Aitutaki at least a few centuries prior to $c a . \mathrm{AD} 1000$, as does recent work elsewhere in the southern Cook Islands. After $c a$. AD 1000, human settlements continued to expand along Aitutaki's western coast, focusing on the newly formed beach ridge. As the ridge grew through storm deposition, these 
occupations were periodically disrupted and specific localities were abandoned, sometimes for several centuries.

Aitutaki may also provide insights as to why early coastal occupations have been difficult to locate in East Polynesia. Present evidence indicates that the period between $c a .3400-1200 \mathrm{BP}$ was one of significant coastal change. Prior to the sea-level decline, sedimentary conditions were more likely erosional than depositional (as is usually the case under transgression), especially if sea-level rise was rapid and reefs were unable to keep pace. The Aitutaki evidence indicates that post-regression conditions were depositional and thus more conducive to preserving archaeological deposits. Changing shoreline conditions and, in particular, erosional forces prior to $c a .1200 \mathrm{BP}$, may be another reason that prehistoric colonial settlements have been elusive in central East Polynesia.

\section{ACKNOWLEDGMENTS}

The Aitutaki research was supported by NSF Grant BSN-8822768; Wenner-Gren Foundation for Anthropological Research Grant 5079; NSF Grant BSR-8607535 (to D. Steadman, New York State Museum); a University of Washington W. W. Stout Fellowship; Sigma Xi, The Scientific Research Society; Director, Makiuti Tongia, of the Cook Island National Museum and Director, Patrick Kirch, of the Thomas Burke Memorial Washington State Museum. The Government of the Cook Islands and the people of Aitutaki graciously permitted and facilitated this research. I am especially indebted to Tony Utanga, Makiuti Tongia, Mayor Tikaka Henry and the Island Council, Nga Tuakura, Bobby Bishop, Mikaela Tumu, Ruru Carl, Oneo Terekia, Tina and Jack Neale and the Teaka and Teaukura families. Lisa Nagaoka, Susan Schubel and Algernon Allen provided invaluable assistance in the field and lab. I thank Brad Evans for the illustrations.

\section{ARChaEological SAMPLes}

\section{Mainland Samples}

Beta-27439. Ureia

Wood charcoal, $6 \mathrm{~g}$, Site AIT-10, Units 1 and 2, Zone J, Level 13, from 7-mm screens. Cal AD 1210 (1260) 1290 at $1 \sigma$.

\section{Beta-25246. Ureia}

Wood charcoal, Site AIT-10, Unit 7, Zone J, Level 10, collected in-situ. Cal AD 1520 (1650) 1950 at $1 \sigma$.

Comment: This date is anomalously young, given the stratigraphic position of Zone $\mathrm{J}$ below securely dated in-situ occupations. The sample probably dates an intrusive post-depositional disturbance, possibly from Zone C.

\section{Beta-40759. Ureia}

$1120 \pm 60$

$\delta^{13} \mathrm{C}=+2.9 \%$

Marine shell (Pinctada margaritifera), $58 \mathrm{~g}$, Site AIT-10, Unit 1, Zone I, Level 11, collected in situ. Cal AD 1280 (1310) 1380 at $1 \sigma$.

Comment: Pinctada was commonly used for fishhooks. This specimen was modified by: 1) removal of the rough and dull exterior to expose the underlying nacre; and 2) flaking along the edge opposite the hinge. Because pearlshell dulls and deteriorates with age, fresh specimens are most often worked 
and the mollusk probably did not die much before its cultural modification. It was probably transported from the lagoon (eastern) side of the island. The calibrated age suggests that the Zone I redeposited cultural materials are nearly contemporaneous with those from Zone G, despite being separated by close to $50 \mathrm{~cm}$ of sterile sands.

Beta-25250. Ureia

$1040 \pm 80$

$\delta^{13} C=-28.8 \%$

Wood charcoal (10 g), Site AIT-10, Unit 3, Zone G, Level 6, from 7-mm screens. Cal AD 900 (1010) 1040 at $1 \sigma$.

Beta-25247. Ureia

$560 \pm 70$

$\delta^{13} C=-28.4 \%$

Wood charcoal, Site AIT-10, Unit 7, Zone G, Level 7, from 7-mm screens. Cal AD 1310 (1410) 1430 at $1 \sigma$.

Comment: The calibrated date is anomalously young for Zone G, and probably reflects cultural activities associated with Zone E. Excavation notes indicate that the top of Zone $\mathrm{G}$ was indistinguishable from the bottom of Zone $\mathrm{E}$ in this unit.

Beta-25249. Ureia

$760 \pm 60$

$\delta^{13} C=-27.1 \%$

Wood charcoal (8 g), Site AIT-10, Unit 10, Zone E, Level 5, below coral slab pavement, from 7-mm screens. Cal AD 1230 (1280) 1290 at $1 \sigma$.

Beta-25248. Ureia

$720 \pm 60$

$\delta^{13} C=-29.5 \%$

Wood charcoal (25 g), Site AIT-10, Unit 7, Zone E, Level 5, from 7-mm screens. Cal AD 1270 (1290) 1300 at $1 \sigma$.

Beta-25251. Ureia

$200 \pm 50$

$\delta^{13} C=-28.4 \%$

Wood charcoal (10 g), Site AIT-10, Unit 2, Zone C, Level 3, from 7-mm screens. Cal AD 1660 (1670, $1780,1800,1950) 1950$ at $1 \sigma$.

$620 \pm 80$

Beta-31604. Hosea

$\delta^{13} C=-27.3 \%$

Wood charcoal (68 g), Site AIT-50, Unit 5, Zone G, Level 7, in-situ sample from charcoal-rich lens. Cal AD $1290(1320,1350,1390) 1410$ at $1 \sigma$.

Comment: This sample dates the basal occupation at Hosea.

Beta-41062. Hosea

$320 \pm 70$

$\delta^{13} C=-24.9 \%$

Wood charcoal (5 g), Site AIT-50, Unit 2, Zone E, Levels 6 and 7, from 7-mm screens. Cal AD 1480 $(1530,1540,1630) 1660$ at $1 \sigma$.

Beta-34330. Aretai

$400 \pm 50$

$\delta^{13} C=-26.3 \%$

Wood charcoal, Site AIT-49, Unit 3, Zone G, Level 2, in-situ sample from hearth. Cal AD 1440 (1470) 1620 at $1 \sigma$.

Comment: This sample dates the basal occupation at Aretai. 


\section{Beta-40762. Aretai}

Wood charcoal (15 g), Site AIT-49, Unit 1, Zone E, from 7-mm screens. Cal AD 1490 (1640) 1660 at $1 \sigma$.

\section{Beta-40760. Poana}

$620 \pm 80$

$\delta^{13} \mathrm{C}=-23.8 \%$

Wood charcoal (11 g), Site AIT-47, Unit 2, Zone M, in-situ sample from hearth. Cal AD 1290 (1320, $1350,1390) 1410$ at $1 \sigma$.

\section{Beta-40761. Mataki}

$210 \pm 50$

$\delta^{13} C=-25.8 \%$

Wood charcoal (14 g), Site AIT-48, Unit 1, Zone E, Level 5, from 7-mm screens. Cal AD 1650 (1670, $1790,1950) 1950$ at $1 \sigma$.

Islet Samples

\section{Beta-25767. Moturakau}

Wood charcoal, Site MR-1 Shelter A, Unit 1, Zone K, Level 15, in-situ sample from hearth. Dates the basal occupation in Shelter A. Cal AD 1060 (1220) 1280 at 1 o.

\section{Beta-41573. Moturakau}

$840 \pm 60$ $\delta^{13} C=-26.0 \%$

Wood charcoal (24 g), Site MR-1 Shelter B, Unit 7, Zone D, Level 8, from 7-mm screens. Cal AD $1160(1220) 1280$ at $1 \sigma$.

Comment: The calibrated age is anomalously old for this level. The sample age correlates closely with Beta-25767, suggesting that both shelters were in use by the 13th century $\mathrm{AD}$.

Beta-33445. Moturakau

Wood charcoal (35 g), Site MR-1 Shelter B, Unit 7, Zone H, Level 11, in-situ sample from oven. Cal $\mathrm{AD} 1290$ (1300) 1390 at $1 \sigma$.

Beta-40341. Moturakau

$670 \pm 60$ $\delta^{13} C=-26.2 \%$

Wood charcoal (51 g), Site MR-1 Shelter B, Unit 8, Zones F and H, Level 10, from 7-mm screens. Cal AD 1290 (1300) 1390 at 1 o.

\section{Beta-40339. Moturakau}

Wood charcoal, Site MR-1 Shelter A, Unit 3, Zone F, Level 12, in-situ sample. Cal AD 1290 (1310, $1360,1380) 1400$ at $1 \sigma$.

\section{Beta-44373. Moturakau}

Wood charcoal, Site MR-1 Shelter B, Unit 8, Zone H, Level 11, in-situ sample from charcoal concentration. Cal AD 1310 (1410) 1430 at 1 o. 
Beta-25766. Moturakau

Wood charcoal, Site MR-1 Shelter A, Unit 1, Zone C, Level 5, from 7-mm screens. Cal AD 1320 (1410) 1440 at $1 \sigma$.

Beta-40340. Moturakau

$530 \pm 60$

$\delta^{13} C=-26.2 \%$ o

Wood charcoal (32 g), Site MR-1 Shelter B, Unit 7, Zone F, Level 10, from 7-mm screens. Cal AD $1400(1420) 1440$ at $1 \sigma$.

Beta-42573. Moturakau

$390 \pm 50$

$\delta^{13} C=-27.3 \%$

Wood charcoal (22 g), Site MR-1 Shelter B, Unit 7, Zone D, Level 7, from 7-mm screens. Cal AD $1450(1480) 1630$ at $1 \sigma$.

Beta-44371. Moturakau

$230 \pm 50$

$\delta^{13} C=-25.9 \%$

Wood charcoal (13 g), Site MR-1 Shelter A, Unit 3, Zone A, Level 4, terrace fill, from 7-mm screens. Sample dates a subsurface boulder-faced terrace. Cal AD 1650 (1660) 1950 at $1 \sigma$.

$180 \pm 50$

Beta-44372. Moturakau

$\delta^{13} C=-27.7 \%$

Wood charcoal (14 g), Site MR-1 Shelter B, Unit 8, Zone C, Level 7, four large chunks from a single log collected in-situ from hearth. Cal AD $1660(1680,1770,1800,1940,1950) 1950$ at $1 \sigma$.

Beta-41572. Moturakau

$50 \pm 60$ $\delta^{13} C=-26.4 \%$

Wood charcoal (17 g), Site MR-1 Shelter B, Unit 7, Zone B, Level 3, in-situ sample from hearth. Cal $\mathrm{AD} 1820$ (1950) 1955 at $1 \sigma$.

\section{SEDIMENTOLOGICAL SAMPLES}

Beta-41061. Amuri District

$3540 \pm 90$

$\delta^{13} C=+1.4 \%$

Marine shell (Asaphis violaceus, $16.5 \mathrm{~g}$; Fragum fragum, $4.8 \mathrm{~g}$; Rhinoclavis aspera, $1.5 \mathrm{~g}$ ), Trench 6 , Layer X, $180 \mathrm{~cm}$ below surface, collected from storm deposit directly below a thin paleosol. Cal BP 3460 (3360) 3260 at $1 \sigma$.

Comment: The three shells were unweathered, indicating deposition soon after death; most likely these individuals died as a direct result of the storm that deposited this layer. Given the frequency of major storm events along this coast, the storm probably did not antedate the development of the paleosol by more than a few centuries. This sample provides a minimal date for the stabilization of inland areas of the coastal plain and a measure of coastal aggradation in this more elevated locality.

\section{REFERENCES}

Allen, M. S. (ms.) 1992a Dynamic Landscapes and Human Subsistence: Archaeological Investigations on Aitutaki Island, Southern Cook Islands. Ph.D. dissertation, University of Washington, Seattle: 557 p.

1992b Temporal variation in Polynesian fishing strategies: The southern Cook Islands in regional per-

spective. Asian Perspectives 31(2): 183-204.

Allen, M. S. and Schubel, S. E. 1990 Recent archaeological research on Aitutaki, Southern Cooks: The Moturakau rockshelter. Journal of the Polynesian Society 99(3): 265-295.

Allen, M. S. and Steadman, D. W. 1990 Excavations at 
the Ureia site, Aitutaki, Cook Islands: Preliminary results. Archaeology in Oceania 25(1): 24-37.

Athens, J. S. and Ward, J. V. 1993 Environmental change and prehistoric Polynesian settlement in Hawai'i. Asian Perspectives 32(2): 205-223.

Bellwood, P. S. 1978 Archaeological research in the Cook Islands. Pacific Anthropological Records 27. Honolulu, Bishop Museum: 214 p.

Crocombe, R. 1964 Land Tenure in the Cook Islands. London, Oxford University Press: $180 \mathrm{p}$

Johnson, K. M. 1967 Village agriculture in Aitutaki, Cook Islands. Pacific Viewpoint Monograph 1. Wellington, Victoria University: $122 \mathrm{p}$.

Kirch, P. V. 1983 Man's role in modifying tropical and subtropical Polynesian ecosystems. Archaeology in Oceania 18(1): 26-31.

Kirch, P. V., Flenley, J. R. and Steadman, D. W. 1991 A radiocarbon chronology for human-induced environmental change on Mangaia, southern Cook Islands, Polynesia. Radiocarbon 33(3): 317-328.

Lamont, F. (ms.) 1990 A 6,000 Year Pollen Record from Mangaia, Cook Islands, South Pacific: Evidence for Early Human Impact. B.Sc. dissertation, School of Geography and Earth Resources, The University of Hull, Hull, England: 57 p.

Nunn, P. D. 1991 Keimami sa Vakila na Liga ni Kalou. Feeling the Hand of God: Human and Nonhuman Impacts on Pacific Island Environments. Honolulu, Environment and Policy Institute, East West Center: 68 p.

Ramenofsky, A. 1987 Vectors of Death. Albuquerque, University of New Mexico Press: 300 p.

Pirazzoli, P. A., Montaggioni, L. F., Salvat, B. and Faure, G. 1988 Late Holocene sea level indicators from twelve atolls in the central and eastern Tuamotus (Pacific Ocean). Coral Reefs 7: 57-68.

Spriggs, M. J. T. (ms.) 1981 Vegetable Kingdoms: Taro Irrigation and Pacific Prehistory. Ph.D. dissertation, Australian National University, Canberra: 203 p.

Steadman, D. 1991 Extinct and extirpated birds from Aitutaki and Atiu, southern Cook Islands. Pacific Science 45(4): 325-347.

Stoddart, D. R. 1975 Almost-atoll of Aitutaki: Geomorphology of reefs and islands. In Stoddart, D. R. and
Gibbs, P. E., eds., Almost-Atoll of Aitutaki: Reef studies in the Cook Islands, South Pacific. Atoll Research Bulletin 190: 31-58.

Stuiver, M., and Becker, B. 1993 Extended ${ }^{14} \mathrm{C}$ data base and revised Calib $3.0{ }^{14} \mathrm{C}$ age calibration program. In Stuiver, M., Long, A., and Kra, R. S., eds., Calibration 1993. Radiocarbon 35(1): 215-230.

1986 High-precision decadal calibration of the radiocarbon time scale, AD 1950-2500 BC. In Stuiver, M. and Kra, R. S., eds., Proceedings of the 12th International ${ }^{14} \mathrm{C}$ Conference. Radiocarbon 28(2B): 863910.

Stuiver, M., Pearson, G. W. and Braziunas, T. 1986 Radiocarbon age calibration of marine samples back to 9000 cal BP. In Stuiver and Kra, R. S., eds., Proceedings of the 12th International ${ }^{14} \mathrm{C}$ Conference. Radiocarbon 28(2B): 980-1021.

Stuiver, M., and Polach, H. A. 1977 Discussion: Reporting of ${ }^{14} \mathrm{C}$ data. Radiocarbon 19(3):355-363.

Stuiver, M. and Reimer, P. J. 1986 A computer program for radiocarbon age calibration. In Stuiver, $M$. and Kra, R. S., eds., Proceedings of the 12th International ${ }^{14} \mathrm{C}$ Conference. Radiocarbon 28(2B): 1022-1030.

Stuiver, M. and Reimer, P. J. 1993 Extended ${ }^{14} \mathrm{C}$ data base and revised CALIB $3.0{ }^{14} \mathrm{C}$ age calibration program. In Stuiver, M., Long, A., and Kra, R. S., eds., Calibration 1993. Radiocarbon 35(1): 215-230.

Sunderland, J. P., and Buzacott, A., eds. 1985 Mission Life in the Islands of the Pacific. Being a Narrative of the Life and Labours of the Reverend A. Buzacott. Rarotonga, Institute of Pacific Studies of the University of the South Pacific, Suva with the Cook Islands Library and Museum, Rarotonga. (Reprinted; originally published 1866, London, John Snow and Co.).

Wood, B. L. and Hay, R. F. 1970 Aitutaki. In Wood, B. L. and Hay, R. F., eds., The Geology of the Cook Islands. New Zealand Geological Survey Bulletin 82: 36-40.

Yonekura, N., Ishii, T., Saito, Y., Maeda, Y., Matsushima, Y., Matsumoto, E. and Kayanne, H. 1988 Holocene fringing reefs and sea-level change in Mangaia Island, southern Cook Islands. Palaeogeography, Palaeoclimatology, Palaeoecology 68: 177-188. 